\title{
Effect of PE film thickness and storage temperature in MAP deastringency of 'Sanggamdungsi' astringent persimmon
}

\author{
Il-Ho Kim ${ }^{1}$, Ji-Young Kim ${ }^{1}$, Hyun-Jin Nam ${ }^{1}$, Ki-U Lee ${ }^{2}$, \\ Doo-Hyun $\mathrm{Cho}^{2}$, Yong-Jae Lee ${ }^{1 *}$ \\ ${ }^{1}$ Department of Horticultural Bioscience, Pusan National University, Miryang 50463, Korea \\ ${ }^{2}$ Sangju Persimmon Research Institute, Gyeongsangbuk-do Agricultural Research and Extension Services, Sangju 37268, Korea
}

\section{PE 필름 두께와 온도에 따른 ‘상감둥시’ 감의 MAP 탈삽 효과}

\author{
김일호 ${ }^{1} \cdot$ 김지영 $^{1} \cdot$ 남현진 $^{1} \cdot$ 이기 우 $^{2} \cdot$ 조두현 $^{2} \cdot$ 이용재 $^{1 *}$ \\ ${ }^{1}$ 부산대학교 원예생명과학과, ${ }^{2}$ 경상북도농업기술원 상주감연구소
}

\begin{abstract}
We investigated the effect of PE film thickness on the modified atmosphere packaging (MAP) deastringency of 'Sanggamdungsi' (Diospyros kaki cv.) astringent persimmon at room temperature $\left(25^{\circ} \mathrm{C}\right)$ and low temperature $\left(-1{ }^{\circ} \mathrm{C}\right)$. The fruits were individually packaged with PE film of which the thickness is $60,80,100,115$ or $130 \mu \mathrm{m}$ and stored at room or low $\left(-1^{\circ} \mathrm{C}\right)$ temperature. At room temperature, firmness shows the highest value (23.3-26.5) at $100 \mu \mathrm{m}$ thickness. Top flesh browning and decay was monitored at 20 days after storage, and peel blackening and style-end softening was negligible at optimal thickness. Therefore, optimal film thickness of deastringency at room temperature is 80-100 $\mu \mathrm{m}$. At this thickness, the astringency was removed after 5 days and the fruits can be distributed until 10 days after the MAP. At low $\left(-1{ }^{\circ} \mathrm{C}\right)$ temperature, firmness was maintained regardless of film thickness. However, the firmness is higher as the film is thicker. Top flesh browning and decay was not occurred even after 90 days after storage. Peel blackening and style-end softening was monitored at 90 days after storage. Off-flavor was monitored at 115 and $130 \mu \mathrm{m}$ thickness. Therefore, optimal film thickness of deastringency at low $\left(-1{ }^{\circ} \mathrm{C}\right)$ temperature is $\mathbf{8 0 - 1 0 0} \mu \mathrm{m}$. At this thickness, the astringency was removed after 50 days and the fruits can be distributed until 80 days after the MAP.
\end{abstract}

Key words : astringent persimmon, deastringency, MAP, storage temperature, quality

\section{서 론}

우리나라에서 많이 생산되는 과실 중의 하나인 감은 수 확 시 삽미의 유무에 따라 떫은감과 단감으로 구분된다. 떫은감은 감말랭이, 반건시 및 곶감에 대한 수요 증가로 2004년경부터 생산량이 급속히 증가하여 2016년 현재 218,076 M/T에 이르고 있다(1). 최근에는 수요에 비해 공급

*Corresponding author. E-mail : yjl@pusan.ac.kr Phone : 82-55-350-5524, Fax : 82-55-350-5529

Received 3 August 2017; Revised 18 September 2017; Accepted 12 October 2017.

Copyright (c) The Korean Society of Food Preservation. All rights reserved.
이 과잉되면서 떫은감을 이용한 새로운 제품 개발이 요구되 고 있는데, 생과 상태에서 떫은맛을 제거한 탈삽 생과가 하나의 대안이 될 수 있을 것으로 생각된다.

떫은감은 단감과 비교하여 과육 내의 가용성 당이 많으 며(2), 품종이 많아 다양한 맛과 숙기를 가진다. 특히, 좋은 품질의 조생종 단감이 거의 없는 현 상황에서 조생종 탈삽 생과는 그 가치가 크다. 또한 떫은감은 단감에 비해 다수성 이며 병충해와 내한성이 강해 재배에도 유리하다(3). 일본 에서는 육질이 부드럽고 당도가 높은 떫은감인 '평핵무 (Hiratanenashi)'와 '도근조생(Tonewase)'을 탈삽하여 생과 로 많이 이용하고 있고(4), 이스라엘은 떫은감인 'Triumph' 품종을 탈삽하여 'Sharon'이라는 상표명으로 세계시장에 수출하고 있다(5). 국내에서도 떫은감 탈삽 생과의 생산과 
수출에 대한 시도가 있었으나 탈삽 후 빠른 연화와 과피흑 변 등의 장해 발생과 탈삽 과실에 대한 소비자의 인식 부족 등으로 아직 그 실적이 미미한 실정이다.

떫은감에서 느끼는 떫은맛은 폴리페놀의 일종인 가용성 타닌(tannin)에 의한 것이다. 타닌 세포에서 용출된 타닌이 혀의 단백질과 결합하여 윤활작용이 약해지면서 떫고 마른 맛을 느끼게 된다. 떫은맛이 없어지는 탈삽은 acetaldehyde 에 의한 것(6,7)과 감이 홍시가 될 때 생성된 펙틴 물질 등의 세포벽 분해산물과 타닌과의 결합에 의한 것 $(8,9)$ 이 있다. Acetaldehyde에 의한 탈삽은 acetaldehyde가 가용성 타닌과 축합하고 중합하여 떫은맛을 느낄 수 없는 고분자의 불용성 타닌으로 되는 것이다(6).

Acetaldehyde와 타닌의 축합과 중합 원리를 이용한 인위 적인 탈삽에는 ethanol을 처리하는 방법(10,11), $\mathrm{CO}_{2}$ 를 처리 하는 방법(11-14) 및 modified atmosphere packaging(MAP) 를 이용하는 방법(15,16)이 사용되고 있다. 이중 MAP 탈삽 은 포장과 과실의 호흡을 통해 조성된 혐기 및 고농도 이산 화탄소 조건으로 acetaldehyde를 생성시켜 탈삽하는 방법이 다. MAP를 이용한 탈삽은 특수한 시설이 필요치 않으며 품종 특성에 맞는 적절한 포장 조건이 이루어지면 탈삽과 저장을 동시에 할 수 있다. 더불어 $\mathrm{MA}$ 포장된 상태에서 유통과 판매가 되므로 상품성 유지에도 효과적이다.

본 연구는 대과종인 '상감둥시'를 대상으로 MAP를 이용 한 탈삽을 수행하였다. '상감둥시'는 상주감연구소에서 김 천지방에 분포하는 지방종 우량계통을 선발한 품종으로, 내한성이 비교적 강하고 꼭지가 크고 단단한 특징을 지니고 있다. 중량은 $300 \mathrm{~g}$ 이상으로 대과이며 연시, 반건시용으로 우수한 특징이 있다. 이 '상감둥시'를 대상으로 상온과 저온 에서 효과적인 MAP 탈삽을 위한 필름의 적정 두께를 구명 하고자 하였다.

\section{재료 및 방법}

\section{실험재료}

본 연구에 사용된 '상감둥시'는 경상북도 상주시 상주감 연구소에서 2015년 10월 14일 수확하여 당일 대학 실험실 로 운반하였다. 운반한 과실은 $25^{\circ} \mathrm{C}$ 실험실에서 overnight하 면서 약 10 시간 정도 온도 평형을 거친 후 상처나 흠이 없는 과실을 선별하여 실험에 사용하였다. 사용된 과실의 중량은 $330 \pm 28.6 \mathrm{~g}$, 경도는 $31.5 \pm 3.6 \mathrm{~N}$ 이었다.

\section{실험처리}

'상감둥시'를 대상으로 상온 $\left(25^{\circ} \mathrm{C}\right)$ 과 저온 $\left(-1^{\circ} \mathrm{C}\right)$ 에서 각 각 탈삽에 적절한 $\mathrm{PE}$ 필름의 두께를 구명하고자 상온 탈삽 시험은 $60,80,100,115,130 \mu \mathrm{m}$ 두께의 polyethylene(PE) 필름을, 저온 탈삽 시험은 $80,100,115,130 \mu \mathrm{m}$ 두께의
$\mathrm{PE}$ 필름으로 낱개 포장하였다. 포장 규격은 $14.5 \mathrm{~cm} \times 18.0$ $\mathrm{cm}$ 이었으며 진공포장 하였다. 포장 후 상온과 저온에서 탈삽을 진행하면서 조사하였다.

\section{탈삽 및 품질 조사}

탈삽은 탈삽지수(astringency index)로 나타내었다. 탈삽 지수는 $5 \% \mathrm{FeCl}_{3}$ 용액에 침지하여 건조한 filter paper에 과실 의 종단면을 압착시켜 군청색으로 착색된 정도에 따라 육안 으로 등급을 판단하였다(17). 발색 정도가 심한 것은 4(탈삽 되지 않은 것), 발색이 전혀 나타나지 않는 것은 0 (탈삽된 것)으로 설정하여 다섯 등급으로 나누었으며, 식용이 가능 한 상태를 1 이하로 판정하였다.

과육의 경도는 물성분석기(TA-XT2, SMS, Surrey, England)를 이용하여 과실 적도 부위의 마주보는 두 곳을 측정하였다. 이 때 과피는 약 $1 \mathrm{~mm}$ 제거하였고 직경 5 $\mathrm{mm}$ 의 탐침으로 $5 \mathrm{~kg}$ 의 힘을 가하면서 $10 \mathrm{~mm}$ 까지 측정하여 최고값으로 나타내었다. 색도(color chart)는 경상남도 농업 기술원 단감연구소에서 제작한 단감 색도계를 이용하여 3(황색)-7(적색)의 index값으로 표현하였다. 과피흑변과 (peel blackening), 과정부연화과(style-end softening), 과육 갈변과(top flesh browning), 부패과 발생률은 다년간 탈삽 연구를 수행해온 전문가 1 인이 육안으로 관찰하여 전체과 실에 대한 발생과실의 백분율로 나타내었다.

\section{통계 분석}

실험 처리구는 완전임의배치법으로 처리당 상온 시험구 는 12 과 저온 시험구는 10 과씩 처리하고 조사하였다. 실험 결과의 통계분석은 IBM SPSS Statistics(22, IBM Corp., Armonk, NY, USA) program으로 ANOVA 분석과 $\mathrm{p}<0.05$ 수 준에서 Duncan's multiple range test를 실시하여 유의성을 검정하였다.

\section{결과 및 고찰}

$\mathrm{MAP}$ 상온 $\left(25^{\circ} \mathrm{C}\right)$ 탈삽 시 과실의 탈삽지수, 경도 및 색도

'상감둥시'를 MAP하여 상온에 보관하면서 필름 두께에 따른 탈삽지수, 경도 및 색도의 변화를 조사하였다(Fig. 1). 필름 두께가 두꺼울수록 탈삽이 빨라지는 경향을 보였으나 두께에 관계없이 모든 처리구에서 5 일만에 식용이 가능한 상태로 탈삽되었다. 이는 3-4일 만에 탈삽되는 constant temperature short duration(CSTD, 95-98\% $\mathrm{CO}_{2}, 24 \mathrm{~h}, 25^{\circ} \mathrm{C}$ ) 탈삽(18)과 비슷한 시간에 탈삽된 것으로 상온에서 MAP 처리를 통하여 비교적 짧은 시간에 탈삽이 가능한 것으로 확인되었다. 필름이 두꺼울수록 탈삽 속도가 빠른 것은 두 꺼울수록 기체투과도가 낮아 포장 내 저농도 산소와 고농도 이산화탄소 조건이 빠르게 조성되고 이로 인하여 혐기호흡 
의 산물인 acetaldehyde가 빠르게 축적되어 탈삽 속도의 차이를 보인 것으로 판단된다(15,20). 10 일에 가장 얇은 60 $\mu \mathrm{m}$ 두께에서 탈삽지수가 오히려 낮은 것은 상대적으로 호 흡속도가 높아 숙성이 빨리 진행되어 펙틴 등의 세포벽
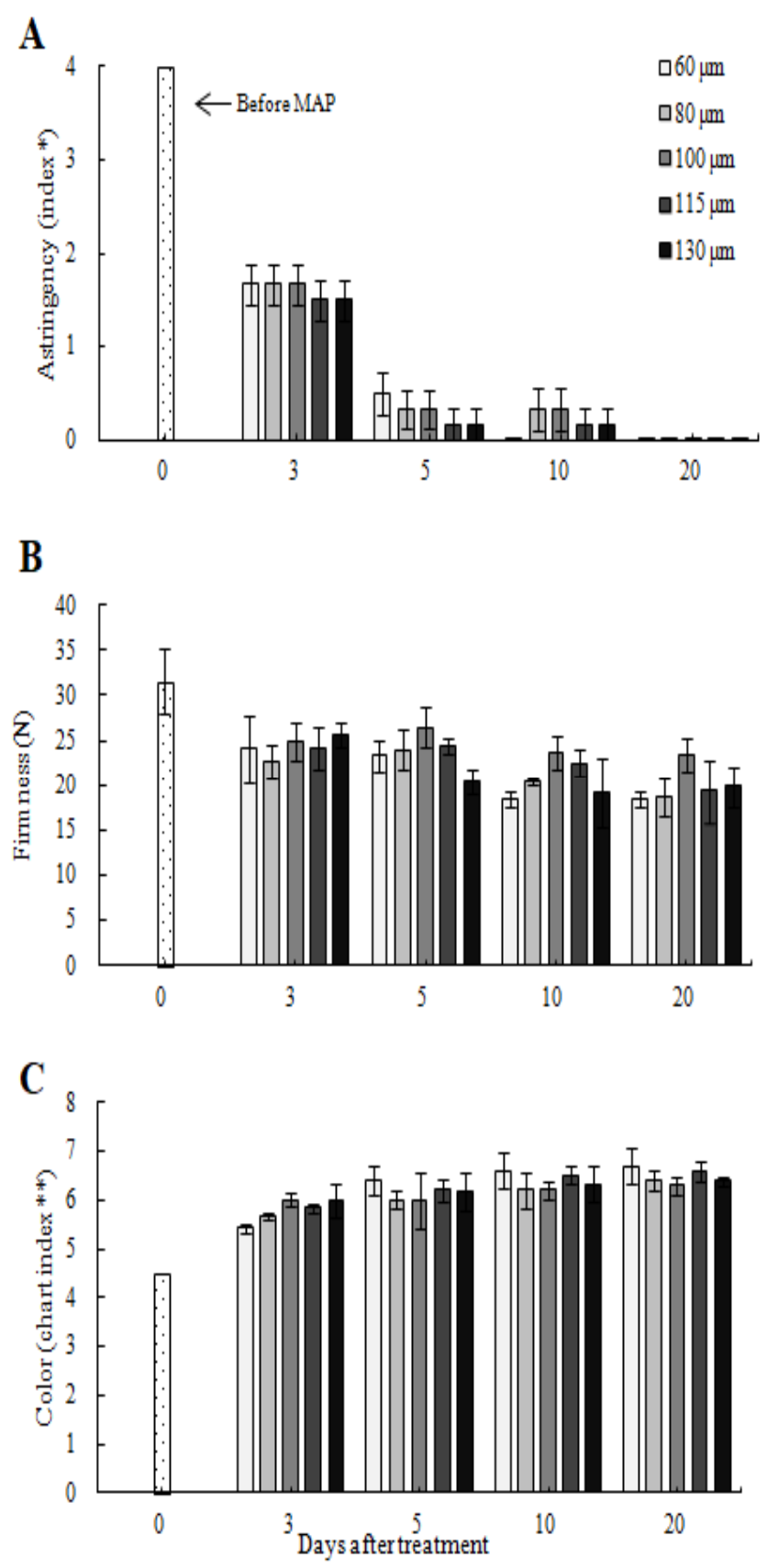

Fig. 1. Changes in degree of astringency (A), flesh firmness (B) and peel color $(C)$ of 'Sanggamdungsi' persimmon affected by PE film thickness of $60,80,100,115,130 \mu \mathrm{m}$ during vacuum packaged individually stored at room temperature $\left(25^{\circ} \mathrm{C}\right)$.

*Astringency was graded to index value from 0 (non-astringency) to 4 (most astringency). Values of 1 or less indicate that fruit was edible.

$* *$ Color was measured to index value from 3 (yellow) to 7 (red) by color chart. Vertical bars indicate SE.
분해 물질이 타닌과 결합한 것(8,9)이 다소의 영향을 미친 것으로 사료된다.

경도는 탈삽 기간이 길어질수록 다소 감소하는 경향이었 으나 비교적 높은 경도를 유지하였다. CTSD 탈삽에서는 탈삽 후 과실이 빨리 연화되는 것이 매우 큰 문제이나(20), 본 MAP 탈삽에서는 이러한 문제가 발생되지 않았다. 이는 95-98\% $\mathrm{CO}_{2}$ 를 24시간 처리 후 바로 해제하는 CTSD 탈삽과 달리 포장을 계속 유지하는 MAP에 의한 지속적인 호흡억 제(15)를 통하여 생리대사를 억제시킨 결과로 해석된다. 탈삽감으로서 '상감둥시' 감의 상품성의 한계 경도는 약 $15 \mathrm{~N}$ 으로 판단되었는데, 모든 두께에서 20 일까지 한계 경 도 이상은 유지되었으나 $100 \mu \mathrm{m}$ 두께에서 가장 높은 값 (23.3-26.5)을 나타냈다.

색도는 모든 처리구에서 5 일까지 증가하다 이후 유지되 는 경향을 보였다. 3 일까지는 필름 두께가 두꺼울수록 다소 높은 경향이었으나 5 일부터는 두께에 따른 차이는 크게 나타나지 않았으나 $60 \mu \mathrm{m}$ 두께가 가장 높았다(Fig. 1C).

MAP 상온 $\left(25^{\circ} \mathrm{C}\right)$ 탈삽시 과피흑변, 과정부연화, 과육갈 변 및 부패 발생률

MAP 후 상온에서 탈삽되는 과정에서 과피흑변, 과정부 연화, 과육갈변 및 부패가 발생되었다(Table 1). 과정부연화 는 과정부의 과육이 연화되는 것으로 연화되지 않으면서 갈변되는 과육갈변과는 구별되었다(Fig. 2). 과정부연화는 3 일부터 발생되기 시작하였으며 발생률이 높지는 않았다. 탈삽일수나 필름두께와 상관없이 발생하였는데, 이는 $\mathrm{MAP}$ 가 직접적인 원인이 아니라 단감에서 보고된 것(21)과 같이 품종의 유전적 특성과 더불어 재배 시 칼슘부족이 원인으로 생각된다. '상감둥시'는 칼슘에 민감한 품종으로 생각되며 차후 칼슘시비와 과정부연화와의 관계에 관한 연구가 필요할 것으로 보인다.

과피흑변은 과피내에 존재하는 타닌성 물질의 일종인 polyphenol이 그 산화 효소인 polyphenol oxidase와의 반응 에 의하여 생기는데, 수소가 수용체가 되어 분자상의 산소 를 흡수하여 polyphenol이 quinone 형태로 산화되고 이러한 quinone류의 물질이 중합하여 흑색 색소인 melanin을 형성 하여 발생하는 것으로 알려져 있다(22,23). 과피흑변은 처 리 5 일까지는 발생되지 않았으나 처리 10 일에는 $60 \mu \mathrm{m}$ 포장의 과실에서 $50 \%$ 로 가장 많이 발생하였으며 $80 \mu \mathrm{m}$ 에 서는 발생되지 않았고 $100,115,130 \mu \mathrm{m}$ 포장의 과실에서 각각 $16.7,16.7,33.3 \%$ 발생하였다. 20 일에는 필름 두께에 관계없이 모든 과실에서 발생하여 상품성이 크게 저하되었 다. $60 \mu \mathrm{m}$ 에서 높은 것은 필름의 기체투과도가 높아 포장 내로 산소가 많이 투과된 것이 원인으로 생각되고, $130 \mu \mathrm{m}$ 에서 높은 것은 수분 투과도가 낮아 포장내 습도가 높은 것이 원인이 아닌가 생각된다. 전체적으로 과피흑변은 필 름 두께 보다는 시간에 더 큰 영향을 받는 것으로 판단되었다. 
과육갈변은 10 일까지는 발생되지 않았으며, 20 일에서 $60,80 \mu \mathrm{m}$ 에서는 발생되지 않았고 $100,115,130 \mu \mathrm{m}$ 에서 각각 $16.7,16.7,50.0 \%$ 가 발생하여 필름의 두께가 두꺼울수

Table 1. The effect of MAP on the quality of 'Sanggamdungsi' persimmon affected by PE film thickness of 60, 80, 100, 115, 130 $\mu \mathrm{m}$ during vacuum packaged individually stored at room temperature $\left(25^{\circ} \mathrm{C}\right)$

\begin{tabular}{|c|c|c|c|c|c|}
\hline $\begin{array}{l}\text { Days after } \\
\text { MAP (day) }\end{array}$ & $\begin{array}{l}\text { Flimthickness } \\
(\mu \mathrm{m})\end{array}$ & $\begin{array}{c}\text { Peel } \\
\text { Blackening (\%) }\end{array}$ & $\begin{array}{c}\text { Style-end } \\
\text { softening (\%) }\end{array}$ & $\begin{array}{c}\text { Top flesh } \\
\text { browning (\%) }\end{array}$ & $\begin{array}{c}\text { Decay } \\
(\%)\end{array}$ \\
\hline \multirow{5}{*}{3} & 60 & $0.0^{\mathrm{cl})}$ & $0.0^{\mathrm{a}}$ & $0.0^{c}$ & $0.0^{\mathrm{b}}$ \\
\hline & 80 & $0.0^{c}$ & $16.7^{\mathrm{a}}$ & $0.0^{c}$ & $0.0^{\mathrm{b}}$ \\
\hline & 100 & $0.0^{c}$ & $0.0^{\mathrm{a}}$ & $0.0^{c}$ & $0.0^{\mathrm{b}}$ \\
\hline & 115 & $0.0^{c}$ & $0.0^{\mathrm{a}}$ & $0.0^{c}$ & $0.0^{\mathrm{b}}$ \\
\hline & 130 & $0.0^{c}$ & $33.3^{\mathrm{a}}$ & $0.0^{c}$ & $0.0^{\mathrm{b}}$ \\
\hline \multirow{5}{*}{5} & 60 & $0.0^{c}$ & $16.7^{\mathrm{a}}$ & $0.0^{c}$ & $0.0^{\mathrm{b}}$ \\
\hline & 80 & $0.0^{\mathrm{c}}$ & $0.0^{\mathrm{a}}$ & $0.0^{c}$ & $0.0^{\mathrm{b}}$ \\
\hline & 100 & $0.0^{\mathrm{c}}$ & $0.0^{\mathrm{a}}$ & $0.0^{\mathrm{c}}$ & $0.0^{\mathrm{b}}$ \\
\hline & 115 & $0.0^{c}$ & $0.0^{\mathrm{a}}$ & $0.0^{c}$ & $0.0^{\mathrm{b}}$ \\
\hline & 130 & $0.0^{c}$ & $16.7^{\mathrm{a}}$ & $0.0^{c}$ & $0.0^{\mathrm{b}}$ \\
\hline \multirow{5}{*}{10} & 60 & $50.0^{\mathrm{b}}$ & $16.7^{\mathrm{a}}$ & $0.0^{\mathrm{C}}$ & $0.0^{\mathrm{b}}$ \\
\hline & 80 & $0.0^{c}$ & $0.0^{\mathrm{a}}$ & $0.0^{c}$ & $0.0^{\mathrm{b}}$ \\
\hline & 100 & $16.7^{\mathrm{bc}}$ & $16.7^{\mathrm{a}}$ & $0.0^{c}$ & $0.0^{\mathrm{b}}$ \\
\hline & 115 & $16.7^{\mathrm{bc}}$ & $33.3^{\mathrm{a}}$ & $0.0^{\mathrm{c}}$ & $0.0^{\mathrm{b}}$ \\
\hline & 130 & $33.3^{\mathrm{bc}}$ & $16.7^{\mathrm{a}}$ & $0.0^{c}$ & $0.0^{\mathrm{b}}$ \\
\hline \multirow{5}{*}{20} & 60 & $100.0^{\mathrm{a}}$ & $0.0^{\mathrm{a}}$ & $0.0^{\mathrm{c}}$ & $16.7^{\mathrm{ab}}$ \\
\hline & 80 & $100.0^{\mathrm{a}}$ & $0.0^{\mathrm{a}}$ & $0.0^{c}$ & $16.7^{\mathrm{ab}}$ \\
\hline & 100 & $100.0^{\mathrm{a}}$ & $0.0^{\mathrm{a}}$ & $16.7^{\mathrm{b}}$ & $50.0^{\mathrm{a}}$ \\
\hline & 115 & $100.0^{\mathrm{a}}$ & $16.7^{\mathrm{a}}$ & $16.7^{\mathrm{b}}$ & $33.3^{\mathrm{ab}}$ \\
\hline & 130 & $100.0^{\mathrm{a}}$ & $16.7^{\mathrm{a}}$ & $50.0^{\mathrm{a}}$ & $50.0^{\mathrm{a}}$ \\
\hline
\end{tabular}

\begin{tabular}{ccccc}
\hline Significance & & & & \\
Days after MAP (A) & $\mathrm{NS}^{2}$ & $* * *$ & $* *$ & $* * *$ \\
Film thickness (B) & NS & NS & NS & NS \\
A $\times$ B & $* * *$ & NS & $*$ & NS \\
\hline
\end{tabular}

${ }^{1)}$ Mean separation within each columns by Duncan's multiple range test at $\mathrm{p}<0.05$. ${ }^{2)} \mathrm{NS}, *, * *$, *** Nonsignificant or significant at $\mathrm{p}<0.05,0.01$ or 0.001 , respectively.
록 많이 발생하는 경향을 보였다. 이는 필름의 두께가 두꺼 울수록 기체투과도가 낮아 포장 내부의 산소농도가 더 빨리 낮아지기 때문으로 생각된다. 과육갈변은 단감 MAP 저장 에서 포장내 산소농도가 $0.3 \%$ 이하에서 다량 발생되는 저 농도 산소 장해로 알려져 있다(24).

부패는 10 일까지는 발생되지 않았으나 20 일에는 16.7 $50.0 \%$ 의 발생률을 보였다. 필름 두께 보다는 시간에 더 큰 영향을 받는 것으로 판단되었다.

이상의 결과와 연구자가 조사를 하면서 느낀 것과 데이 터 값의 증가와 감소의 기울기 등을 고려하여 종합적으로 살펴보면 '상감둥시' 상온 MAP 탈삽은 PE 필름 80-100 $\mu \mathrm{m}$ 두께에서 5 일 만에 탈삽되며 10 일까지 상품성 있는 유통이 가능한 것으로 추정되었다.

MAP 저온 $\left(-1{ }^{\circ} \mathrm{C}\right)$ 탈삽시 과실의 탈삽지수, 경도 및 색도

'상감둥시'를 MAP하여 저온에서 탈삽 시 필름 두께에 따른 탈삽지수, 경도 및 색도를 조사하였다(Fig. 3). 탈삽은 30 일까지는 필름 두께가 두꺼울 수록 탈삽 속도가 빨랐으 며, 상온 탈삽 보다 필름 두께에 따른 탈삽 속도 차이가 더 크게 나타났다. 30 일에 $115,130 \mu \mathrm{m}$ 포장의 과실에서는 식용이 가능한 상태로 탈삽되었으나 나머지 필름에서는 탈삽지수 1.8-2.3수준으로 탈삽이 완료되지 않았다. 60 일에 는 모든 처리구에서 탈삽지수가 0.0 으로 나타났는데 50 일 경에 완전히 탈삽된 것으로 판단된다. 상온에서 5 일만에 탈삽된 것에 비해 비교적 긴 시간이 걸렸으나 저온에서는 50 일 정도에 탈삽이 가능한 것으로 판단되었다.

경도는 기간이 길어질수록 다소 감소하는 경향을 보였다 (Fig. 3B). 두께에 따른 큰 차이는 없었으나 두께가 두꺼울수 록 경도가 높은 경향을 보였다. 이는 필름 두께가 두꺼울수 록 호흡이 더 많이 억제되어 숙성이 지연되는데 기인하는 것으로 생각된다. 색도는 모든 처리구에서 기간이 길어질 수록 점차 증가하는 경향을 보였으며, 필름 두께에 따른 차이는 크지 않았다.
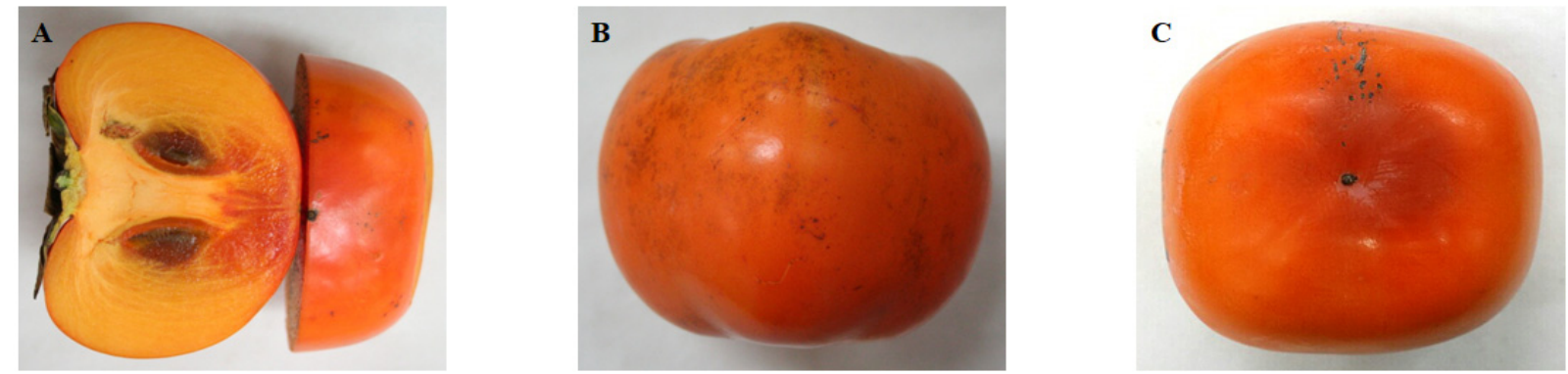

Fig. 2. Types of disorder of 'Sanggamdungsi' persimmon affected by PE film thickness at room temperature $\left(25^{\circ} \mathrm{C}\right)$.

A, style-end softening; B, peel blackening; C, top flesh browning. 

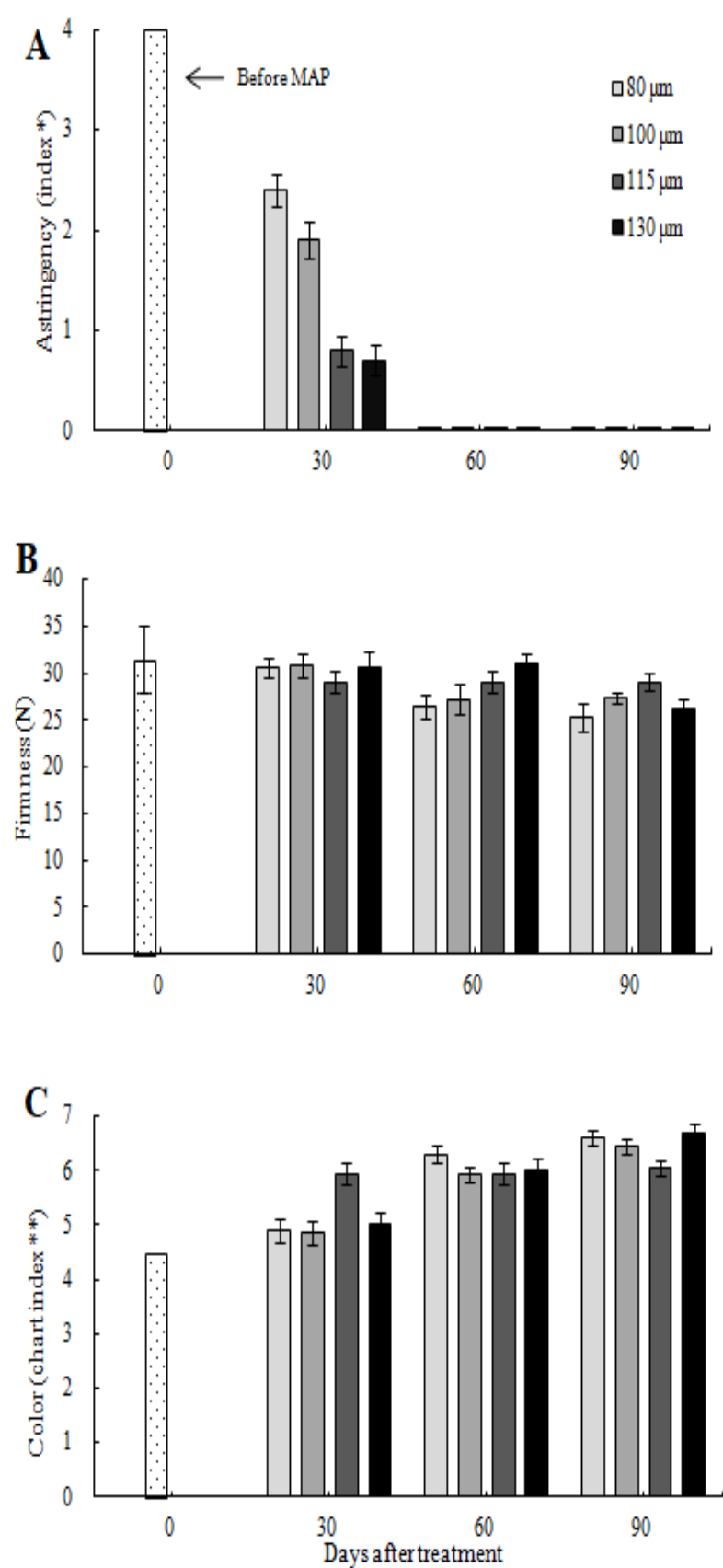

Fig. 3. Changes in degree of astringency (A), flesh firmness (B) and peel color (C) of 'Sanggamdungsi' persimmon affected by PE film thickness of $80,100,115,130 \mu \mathrm{m}$ during vacuum packaged individually stored at room temperature $\left(-1^{\circ} \mathrm{C}\right)$.

* Astringency was graded to index value from 0 (non-astringency) to 4 (most astringency). Values of 1 or less indicate that fruit was edible.

** Color was measured to index value from 3 (yellow) to 7 (red) by color chart. Vertical bars indicate SE.

$\mathrm{MAP}$ 저온 $\left(-1^{\circ} \mathrm{C}\right)$ 탈삽시 과피흑변, 과정부연화, 과육갈 변 및 부패 발생률

‘상감둥시'를 MAP 후 저온에서 탈삽 시 저장 90 일까지 과육갈변과 부패는 발생되지 않았으나 과정부연화와 과피 흑변이 발생되었으며(Table 2), 90일에 115와 $130 \mu \mathrm{m}$ 에서
이취가 발생되는 문제가 있었다(data not shown). 과정부연 화는 60 일까지는 거의 발생되지 않았으며 90 일에는 115 $\mu \mathrm{m}$ 포장의 과실을 제외한 나머지 처리구에서 30-50\% 발생 되었다. 과피흑변은 60 일까지는 발생되지 않았으나 90 일에 발생되었으며 필름이 두꺼울수록 많이 발생되었다. 45-60 $\mu \mathrm{m}$ 두께의 PE 필름을 사용하는 단감 MAP 저장에서 과피흑 변은 두께가 얇을수록 포장 내 산소농도가 높아 산화가 촉진되어 많이 발생되는 것으로 알려져 있는데 $(25,26)$, 본 연구에서는 필름 두께가 두꺼울수록 과피흑변이 많이 발생 되는 상이한 결과를 나타내었는데 이는 상온과 마찬가지로 일정 두께 이상에서는 이미 낮아진 산소 농도보다 높은 습도가 과피흑변 발생에 더 큰 영향을 미친 것으로 생각된 다.

과육갈변은 저온에서는 발생되지 않았다. 이는 상온에 비해 저온에서 포장내 저농도 산소조건이 급속도로 진행되 지 않기 때문으로 판단된다.

부패는 모든 필름 두께에서 90 일까지 전혀 발생되지 않 았다. 이는 저온과 MAP 조건이 부패균의 발생을 강하게 억제한 효과로 해석된다.

이상의 결과와 연구자가 조사를 하면서 느낀 것과 데이 터 값의 증가와 감소의 기울기 등을 고려하여 종합적으로 살펴보면 '상감둥시' 감의 저온 MAP 탈삽은 PE 필름

Table 2. The effect of MAP on the quality of 'Sanggamdungsi' persimmon affected by PE film thickness of 80, 100, 115, $130 \mu \mathrm{m}$ during vacuum packaged individually stored at room temperature $\left(-1^{\circ} \mathrm{C}\right)$

Days after Film thickness Peel Blackening Style-end Top flesh Decay \begin{tabular}{lllll} 
MAP (day) $\quad(\mu \mathrm{m})$ & $(\%)$ & softening $(\%)$ & browning $(\%)$ & $(\%)$ \\
\hline
\end{tabular}

\begin{tabular}{|c|c|c|c|c|c|}
\hline \multirow{4}{*}{30} & 80 & $0.0^{\mathrm{dl})}$ & $0.0^{c}$ & $0.0^{\mathrm{a}}$ & $0.0^{\mathrm{a}}$ \\
\hline & 100 & $0.0^{\mathrm{d}}$ & $0.0^{\mathrm{c}}$ & $0.0^{\mathrm{a}}$ & $0.0^{\mathrm{a}}$ \\
\hline & 115 & $0.0^{\mathrm{d}}$ & $0.0^{\mathrm{c}}$ & $0.0^{\mathrm{a}}$ & $0.0^{\mathrm{a}}$ \\
\hline & 130 & $0.0^{\mathrm{d}}$ & $0.0^{c}$ & $0.0^{\mathrm{a}}$ & $0.0^{\mathrm{a}}$ \\
\hline \multirow{4}{*}{60} & 80 & $0.0^{d}$ & $10.0^{\mathrm{ab}}$ & $0.0^{\mathrm{a}}$ & $0.0^{\mathrm{a}}$ \\
\hline & 100 & $0.0^{\mathrm{d}}$ & $0.0^{\mathrm{c}}$ & $0.0^{\mathrm{a}}$ & $0.0^{\mathrm{a}}$ \\
\hline & 115 & $0.0^{\mathrm{d}}$ & $0.0^{c}$ & $0.0^{\mathrm{a}}$ & $0.0^{\mathrm{a}}$ \\
\hline & 130 & $0.0^{\mathrm{d}}$ & $0.0^{c}$ & $0.0^{\mathrm{a}}$ & $0.0^{\mathrm{a}}$ \\
\hline \multirow{4}{*}{90} & 80 & $30.0^{c}$ & $30.0^{\mathrm{ab}}$ & $0.0^{\mathrm{a}}$ & $0.0^{\mathrm{a}}$ \\
\hline & 100 & $50.0^{\mathrm{b}}$ & $50.0^{\mathrm{a}}$ & $0.0^{\mathrm{a}}$ & $0.0^{\mathrm{a}}$ \\
\hline & 115 & $50.0^{\mathrm{b}}$ & $0.0^{\mathrm{c}}$ & $0.0^{\mathrm{a}}$ & $0.0^{\mathrm{a}}$ \\
\hline & 130 & $70.0^{\mathrm{a}}$ & $40.0^{\mathrm{ab}}$ & $0.0^{\mathrm{a}}$ & $0.0^{\mathrm{a}}$ \\
\hline \multicolumn{6}{|c|}{ Significance } \\
\hline \multicolumn{2}{|c|}{ Days after MAP (A) } & $\left.* * *^{2}\right)$ & $* *$ & NS & NS \\
\hline \multicolumn{2}{|c|}{ Film thickness (B) } & NS & NS & NS & NS \\
\hline \multicolumn{2}{|c|}{$\mathrm{A} \times \mathrm{B}$} & $* * *$ & * & NS & NS \\
\hline
\end{tabular}

${ }^{1)}$ Mean separation within each columns by Duncan's multiple range test at $p<0.05$. ${ }^{2}$ NS, ***, *** Nonsignificant or significant at $\mathrm{p}<0.05,0.01$ or 0.001 , respectively. 
80-100 $\mu \mathrm{m}$ 두께에서 약 50일 만에 탈삽되며 80일까지 상품 성을 유지한 유통이 가능한 것으로 추정되었다.

\section{요 약}

상온 $\left(25^{\circ} \mathrm{C}\right)$ 과 저온 $\left(-1^{\circ} \mathrm{C}\right)$ 에서 modified atmosphere packaging (MAP)를 이용한 '상감둥시' 감의 탈삽처리를 통하여 각 온도에서 $\mathrm{PE}$ 필름의 적정 두께를 구명하고자 하였다. 60 (상 온에서만 사용), $80,100,115,130 \mu \mathrm{m}$ 두께의 $\mathrm{PE}$ 필름을 이용하여 낱개 진공포장 후 각각 상온과 저온에서 탈삽하였 다. 상온에서 탈삽은 필름 두께가 두꺼울수록 속도가 빠른 경향이었으나 모든 처리구에서 두께에 관계없이 5 일 만에 식용이 가능한 상태로 탈삽되었다. 경도는 모든 처리구에 서 비교적 높게 유지되었다. 과육갈변(top flesh browning) 과 부패는 20 일에 발생되었으며 과피흑변(peel blackening) 과 과정부연화(style-end softening)는 적정 두께에서 거의 문제 되지 않았다. 상온 $\mathrm{MAP}$ 탈삽의 적정 $\mathrm{PE}$ 필름 두께는 80-100 $\mu \mathrm{m}$ 로, 이 두께에서 5일만에 탈삽되어 10 일까지 상 품성을 유지한 유통이 가능한 것으로 판단되었다.

저온에서의 탈삽도 필름 두께가 두꺼울수록 속도가 빨랐 으며 50 일경에 두께에 관계없이 완전히 탈삽되었다. 경도 는 필름 두께에 따른 큰 차이는 없었으나 두꺼울수록 높은 경향을 보였다.

과육갈변과 부패는 필름 두께와 관계없이 모든 처리구에 서 90 일까지 발생되지 않았다. 과피흑변과 과정부연화는 90 일에 발생되었으며 115 와 $130 \mu \mathrm{m}$ 두께에서 이취가 발생 되었다. 저온 MAP 탈삽의 적정 $\mathrm{PE}$ 필름 두께는 80-100 $\mu \mathrm{m}$ 로, 이 두께에서 50 일만에 탈삽되어 80 일까지 상품성을 유지한 유통이 가능한 것으로 판단되었다.

\section{감사의 글}

본 연구는 농촌진흥청 공동연구사업(과제번호:PJ01166403) 의 지원에 의해 이루어진 것으로 이에 감사드립니다.

\section{References}

1. Korea Statistical Information Service. http://kosis.kr /ups/ups_01List.jsp?pubcode=IG (accessed August 2017)

2. Nam HC, Lee HJ, Hong SJ, Kim SJ, Kim TC (1998) Varietal differences in fruit characteristics of sweet and astringent persimmons (Diospyros kaki Thunb.). Hortic Environ Biotechnol, 39, 707-712

3. Hong SG, Hwang J (1980) Difference in Freezing
Resistance between Common and Sweet Persimmon. J Forest sci and technol, 48, 25-28

4. Itamura H, Zheng Q, Akaura K (2004) Industry and research on persimmon in Japan. In : Proceedings of the third international symposium on persimmon, Park YM, Kang SM (Editors), ISHS, Acta Horticulturae 685, 37-43

5. Llácer G, Badenes ML (2002) Persimmon production and market. In : Bellini E, Giordani E (Editors), First Mediterrance symposium on persimmon, CIHEAM, Zaragoza, Spain, 51, 9-21

6. Matuo T, Ito S, Ben-Arie R (1991) A model experiment for elucidating the mechanism of astringency removal in persimmon fruit using respiration inhibitors. J Japan Soc Hort Sci, 60, 437-442

7. Sohn TH, Choi CJ, Cho RK, Seog HM, Seong CH, Seo OS, Ha YS, Kang JH (1978) Studies on the utilization of persimmons: (Part 5) Investigation of the optimum thickness of film bag for poly ethylene film storage of astringent variety. Korean J Food Sci and Technol, 10, 73-77

8. Taira S, Ono M (1997) Reduction of astringency in persimmon caused by adhesion of tannins to cell wall fragments. In : Proceedings of the first international symposium on persimmon, Subhadrabandhu S (Editor), ISHS, Acta Horticulturae, 436, 235-241

9. Taira S, Ono M, Matsumoto N (1997) Reduction of persimmon astringency by complex formation between pectin and tannins. Postharvest Biol Technol, 12, 265-271

10. Kato K (1990) Astringency removal and ripening in persimmons treated with ethanol and ethylene. HortScience, 25, 205-207

11. Kim AJ (1994) Studies on the deastringency of astringent persimmon fruit. MS Thesis, Seoul University, Korea

12. Pesis E, Levi A, Ben-Arie R (1988) Role of acetaldehyde production in the removal of astringency from persimmon fruits under various modified atmospheres. J Food Sci, 53, 153-156

13. Byun HS, Park SH, Roh YK, Sung JJ (1999) Changes in the quality of astringent persimmon during removal of astringency by carbon dioxide. Korean J Postharvest Sci Technol, 6, 392-397

14. Ham YJ, Park YM (2003) Evaluation of astringency removal process in carbon dioxide flushing system and storability of 'Sagoksi' persimmon fruits. J Korean Soc Hort Sci, 44, 417-421

15. Pesis E, Levi A, Ben-Arie R (1986) Deastringency of persimmon fruits by creating a modified atmosphere in 
polyethylene bags. J Food Sci, 51, 1014-1016

16. Seong JH (1994) Investigation on the condition of the removal of astringency during MA storage of astringent persimmon variety. Korean J Postharvest Sci Technol Agric Products, 1, 15-20

17. Gazit S, Levy Y (1963) Astringency and its removal in persimmons. Israel J Agr Res, 13, 125-132

18. Kim HC, Bae KS, Hong JU, Kim TC (2005) Shelf-life of de-astringent fruits with treating high carbon dioxide in astringent persimmon cultivars. Kor $\mathrm{J}$ Hort Sci Technol, 23, 413-417

19. Seong JH, Goo MS, Chung HS (2008) Changes of quality and astringency of persimmon due to modified atmosphere packaging. Korean J Food Preserv, 15, 225-230

20. No JK, Lee MH (1998) Removal of astringency in persimmons by chitosan. J Korean Soc Food Sci Nutr, 27, 648-652

21. Moon BW, Kang IK, Lee YC, Choi JS (2002) Effects of tree-spray of liquid calcium compounds on the mineral nutrients, blossom-end browning and quality of non- astringent persimmon fruits. Hortic Environ Biotechnol, 43, 54-57

22. Thomson RH (1964) Structure and reactivity of phenolic compounds. In : Biochemistry of phenolic compounds, Harborne JB (Editor), Academic Press, London, England, p 1-32

23. Macheix JJ, Fleuriet A, Billot J (1990) Changes and metabolism of phenolic compounds in fruits. In : Fruit phenolics, CRC Press, Inc. Boca Raton, Florida, USA, p 149-221

24. Lee YJ (2004) Optimal dimension of PE film bag according to fruit size in MAP storage of 'Fuyu' persimmon fruit. Korean J Food Sci Technol, 36, 733-739

25. Lee YJ (1998) Developmental aspects and casual factors affecting the incidence of black stain and flesh browning disorder during storage of 'Fuyu' persimmon (Diospyros kaki T.). Ph D Thesis, Donga University, Korea

26. Park JE (1999) Observation of the discolored tissues and occurrence of blackening and flesh browning disorder of persimmon (Fuyu) accoding to the PE film thickness. $\mathrm{Ph}$ D Thesis, Donga University, Korea, p 10-12 